ACTA VET. BRNO, 55, 1986: 305-317

\title{
GENETIC CONTRIBUTION OF MILK YIELD IN CROSSES OF THE BOHEMIAN PIED CATTLE WITH THE RED PIED HOLSTEIN AND AYRSHIRE CATTLE
}

\section{P. BRAUNER}

Department of Prevention of Pig Diseases, Animal Breeding and Zoohygiene, University of Veterinary Science, 61242 Brno

Received October 3, 1985

\section{A b s tract}

B r a u n e r P . : Genetic Contribution of Milk Yield in Crosses of the Bohemian Pied Cattle with the Red Pied Holstein and Ayrshire Cattle. Acta vet. Brno, 55, 1986: 305-317.

In comparison of crosses of the Bohemian Pied $X$. Ayrshire cattle (CA) and dairy cows of the Bohemian Pied cattle (C), the highest milk yield was found in crosses of the Bohemian Pied $X$ Red Holstein (CR) cattle in all three lactations. In the CR crosses also the fat per cent and total fat yield were very favourable. The sensitivity and response to housing conditions was higher in the CR. crosses and worsened their condition during the period of the maximum lactation. As concerns the index of persistence $P$. (i.e. the ratio between the milk yield in the first and sectond 100 days of lactation), no significant differences were found among the groups compared. For the lst lactation, the grade of persistence in all three breeding groups was good and the course of the lactation curve was physiological, whereas for the 2 nd and 3 rd lactation the persistence was less satisfactory and the course of the lactation curve tended to be steep. In all the three breeding groups, $25 \%$ of the lactations were abnormal. With continuing lactations, the occurrence of abnormal lactations was more frequent in the $C R$ crosses and breeding cows of group $C$, while the percentage of abnormal lactations was the lowest in the CA crosses. When comparing the milk yield of the group of dairy cows investigated with that of their mothers, it was found that the CR crosses showed a higher milk production in all the three lactations, this difference being highly significant in the lst lactation. A similar result was found in the dairy cows of group $C$, whereas the $C A$ crosses did not reach the milk yield of their mothers in any of the three lactations.

Cattle crossing, Bohemian Pied, Ayrshire, Red Holstein, milk yield, milk fat, course of lactation.

In order to increase milk production, improvement breeding was performed with dairy breeds of cattle in a part of the popu- 
lation of the Bohemian Pied cattle. The purpose of these investigations was to evaluate milk production and other commercially important traits of crosses of the Bohemian.cattle with the Red Holstein breed (CR) and Ayrshire (CA) as compared with the Bohemian Pied breed (C).

S u chánek (1970) evaluated the results of improvement crossing of the Bohemian Pied cattle with Ayrshire in submontane and mountain regions; in the CA crosses of the $F$ and $F$ generations he found that the milk yield was higher in the lst and 3 rd lactation by $300-800 \mathrm{~kg}$ of milk than in the $C$ breed of the same age. S u chánek et al. (1972) compared the CA crosses with group C of the same age and found that the CA crosses produced by 224 - $993 \mathrm{~kg}$ of milk more. Rü egsegger (1978) studied the milk yield of crosses of the Simmenthal with Holstein cattle in various regions of Switzerland; the crosses produced $854-1342 \mathrm{~kg}$ of milk and $0.01-0.20 \%$ of fat more than the Simmenthal dairy cows. According to $\mathrm{Such}$ a $\mathrm{nek}$ and $\mathrm{Golda}$ (1979), in a national average the CA crosses produced $174-444 \mathrm{~kg}$ of milk more in the lst lactation and $190-329 \mathrm{~kg}$ of milk more in the 2nd and following lactations. $0 \mathrm{p}$ i c h a 1 (1979) compared the milk yield in primiparas of the Bohemian Pied cattle which reached $2585 \mathrm{~kg}$ and $4.06 \%$ fat content with the performance of the CA crosses which produced $2906 \mathrm{~kg}$ of milk with $4.19 \%$ of fat. In the 2nd lactation, the milk yield of cows of group $C$ reached $3409 \mathrm{~kg}$ of milk with $3.95 \%$ of fat, while in the CA crosses $3733 \mathrm{~kg}$ of milk and $4.07 \%$ of fat. In the USSR, Sokolova (1979) reported that Holstein - Friesian bulls increased the milk yield in crosses of the $F$ generation during the lst lactation by $812 \mathrm{~kg}$ as compared with their pure-bred Simmenthals. Such a nek et al. (1980) reported that CA crosses, as compared with dairy cows of group $C$ of the same age, showed, on average, a higher milk yield during the lst standardized lactation by 148 - $328 \mathrm{~kg}$ of milk and $0.10 \%$ of fat. Koub ik (1981) evaluated the CA crosses during the. 2nd and following lactations when their milk yield reached 4556 of milk. Dairy cows in breeding herds produced $5044 \mathrm{~kg}$ of milk with $4.00 \%$ of fat in maximal lactations. Jongeling (1981) stated that crossing with the Finnish Ayrshire cattle in Germany did not meet the expectations, while crossing with the Red Holstein breed increased milk yield. U I r y C h and S U C h a nek (1981) evaluated the performance of various types of crosses; in CA and CR crosses the milk yield was higher by as much as $642 \mathrm{~kg}$ of milk as compared with C cows of the same age. More significant differences in the milk fat content were not observed. When crossing the swiss Simmenthal cattle with the Red Holstein, Schmidlin (1980) observed a marked increase in the milk yield but also a significant decrease in the fat percentage. Suchánek (1981) evaluated CR crosses which had a higher milk yield in the lst lactation by $400 \mathrm{~kg}$, decrease of the fat content by $0.07 \%$ and lower proportion of abnormal lactations as compared with group $C$. In the $C R$ crosses, Brauner and Suchánek (1982) showed that the decrease of the fat content and proteins was negative. They compared their results with studies carried out in Switzerland by Baumgartner and $H u t z l i c h$ (1976) who drew attention to the fact that CR crosses were more sensitive and demanding to the conditions of their environment. In dairy cows of the czech 
Red Pied cattle, Suchánek et al. (1984) reported an average milk yield of $3022 \mathrm{~kg}$ in the lst lactation. During the lst lactation, the CA 50 crosses produced $3447 \mathrm{~kg}$ of milk with an average fat content of $4.08-4.10 \%$, the CR 50 crosses produced $3650 \mathrm{~kg}$ of milk. During the $3 \mathrm{rd}$ and following lactations, the CR crosses produced $4242 \mathrm{~kg}$ of milk. In crosses with more than $50 \%$ of Holstein blood, the milk yield in the lst lactation did not increase because the standard of nutrition was not sufficient any more to manifest their productive potential.

\section{Materials and Methods}

Investigations of the subject section of the research stage were carried out under usual conditions of the Veterinary School Training Farm of the University of Veterinary Science in Novy Jičn. The research task was solved as a comparative experiment with three groups of breeding cows: Czech Red Pied $(C n=48)$, crosses Bohemian Pied X Red Holstein with a $50 \%$ proportion of blood (CR $n=62$ ) and crosses Bohemian Pied $x$ Ayrshire with a blood proportion ranging from 25 to $53.25 \%(C A n=65)$. In order to ensure the same environmental conditions, these breeding groups were concentrated in a barn at the Ženklava farm. The experimental groups were studied from June 1979 till March 1984. Over this period it was possible to evaluate the groups during the lst to 3 rd lactations. Milk yield in the lst, 2nd and $3 r d$ lactations was evaluated on the basis of data of performance testing for the standardized 305-day lactation, taking into account lactations lasting 250 to 305 days. The following indices of milk yield were studied: the amount of milk in $\mathrm{kg}$, fat in $\mathrm{kg}$, fat content in \% and the course of lactation in terms of the index of persistence $P_{2}$. Mutual comparisons of these indices of milk yield were ${ }^{2}$ erformed both in breeding groups and within the individual breeding groups according to the sequence of lactation. Milk yields of the individual dairy cows were compared with those of their mothers. Compared was also the milk production in experimental $C R$ crosses and cows of the same age - also CR crosses (B) - housed in another environment in Bartošovice.

Abnormal lactations were observed in all the dairy cows of the groups compared.

Data obtained were analyzed using mathematical-statistical methods.

\section{Results}

Tab. 1 shows the distribution into categories according to the per cent of milk yield in the lst lactation; in CR crosses, the milk yield was the highest $(30.65 \%)$ and ranged from 3501 to $4000 \mathrm{~kg}$ of milk. In group $C$ and $C A$, the highest per cent of dairy cows was in the category of 2501 to $3000 \mathrm{~kg}$ of milk for the lst standardized lactation, i. e. $29.17 \%$ and $33.85 \%$, respectively. For the 2nd lactation the percentage was the same for the categories of $3001-3500$ and $3501-4000 \mathrm{~kg}$ of milk. 
Table 1

Percentual distribution of experimental dairy cows according to their milk yield during a standardized lactation.

\begin{tabular}{|c|c|c|c|c|c|c|}
\hline \multirow{2}{*}{ Group } & \multirow{2}{*}{$\begin{array}{l}\text { Number of } \\
\text { animals } \\
\text { studied }\end{array}$} & \multicolumn{5}{|c|}{ Milk yield in $\mathrm{kg}$ in the lst lactation } \\
\hline & & 2500 & $2501-3000$ & $3001-3500$ & $3501-4000$ & 4001 \\
\hline \multirow[t]{2}{*}{$\begin{array}{l}\text { CR } \\
C \\
C A\end{array}$} & $\begin{array}{l}62 \\
48 \\
65\end{array}$ & $\begin{array}{l}22 . \overline{9} \\
13.9\end{array}$ & $\begin{array}{l}25.8 \\
29.2 \\
33.9\end{array}$ & $\begin{array}{l}25.8 \\
20.8 \\
29.2\end{array}$ & $\begin{array}{l}30.7 \\
27.1 \\
23.1\end{array}$ & $\begin{array}{r}17.7 \\
- \\
-\end{array}$ \\
\hline & & \multicolumn{5}{|c|}{ Milk yield in $\mathrm{kg}$ in the $2 \mathrm{nd}$ lactation } \\
\hline \multirow[t]{2}{*}{$\begin{array}{l}\text { CR } \\
C \\
C A\end{array}$} & $\begin{array}{l}44 \\
31 \\
41\end{array}$ & $\begin{array}{l}-\overline{1} \\
14.6\end{array}$ & $\begin{array}{l}22.7 \\
29.0 \\
31.7\end{array}$ & $\begin{array}{r}27.3 \\
-22.6 \\
29.3\end{array}$ & $\begin{array}{l}27.3 \\
16.1 \\
24.4\end{array}$ & $\begin{array}{r}22.7 \\
16.1 \\
-\end{array}$ \\
\hline & & \multicolumn{5}{|c|}{ Milk yield in $\mathrm{kg}$ in the 3rd lactation } \\
\hline $\begin{array}{l}\text { CR } \\
C \\
C A\end{array}$ & $\begin{array}{l}32 \\
19 \\
34\end{array}$ & $\begin{array}{l}- \\
-\end{array}$ & $\begin{array}{r}6.3 \\
15.8 \\
11.8\end{array}$ & $\begin{array}{l}15.6 \\
36.8 \\
29.4\end{array}$ & $\begin{array}{l}43.8 \\
21.1 \\
44.1\end{array}$ & $\begin{array}{l}34.4 \\
26.3 \\
14.7\end{array}$ \\
\hline
\end{tabular}

Table 2

Results of performance testing of dairy cows of the individual breeding groups according to standardized lactations

\begin{tabular}{lllllll}
\hline Group & $\begin{array}{l}\text { Number } \\
\text { of } \\
\text { animals }\end{array}$ & $\begin{array}{l}\text { Milk } \\
\text { in kg }\end{array}$ & $\%$ & $\mathrm{~kg}$ & Index of persistence \\
\hline Tst lactation & 62 & 3446.1 & 4.06 & 139.11 & 73.61 \\
CR & 48 & 2964.0 & 3.90 & 115.19 & 76.83 \\
C & 65 & 3094.9 & 4.11 & 127.06 & 76.94 \\
CA & & & & & \\
2nd lactation & 44 & 3577.0 & 4.23 & 151.16 & 66.95 \\
CR & 31 & 3243.8 & 4.13 & 133.81 & 67.23 \\
C & 41 & 3116.8 & 4.18 & 129.71 & 67.49 \\
CA & & & & & \\
3rd lactation & 32 & 3885.3 & 4.16 & 161.34 & 65.25 \\
CR & 19 & 3603.5 & 4.10 & 147.95 & 68.00 \\
C & 34 & 3558.2 & 4.37 & 155.85 & 67.15 \\
CA & & & & & \\
\hline
\end{tabular}


i. e. $43.75 \%$ and $44.12 \%$, respectively. The highest representation of group C was in category 3001 - $3500 \mathrm{~kg}$ of milk, i. e. $36.84 \%$.

Due to culling, the number of animals investigated decreased in the following individual lactations.

Tab. 2 shows the results of performance testing of dairy cows of the individual breeding groups according to the sequence of lactation. The highest average amount of milk for the lst lactation was observed in CR ( $3446.05 \mathrm{~kg}$ ); CA crosses produced by $351.13 \mathrm{~kg}$ of milk less and group C by $482.09 \mathrm{~kg}$ of milk less than the CR crosses. Tab. 3 shows the results of statistical evaluation. Fat content was the highest in CR crosses, i. e. $4.11 \%$; the fat content in the CR and C groups was by $0.05 \%$ and $0.21 \%$ lower, respectively, than that of the CA crosses. From the aspect of the total amount of fat for the lst lactation, the highest value was found in the CR crosses, i. e. 139.11 kg; in the CA crosses and group C, the amount of fat was by $12.05 \mathrm{~kg}$ and $23.92 \mathrm{~kg}$ of fat lower, respectively, than in the CR crosses. The index of persistence in all the breeding groups CR (73.61), $C(76.83)$ and $C A(76.94)$ shows that the grade of persistence is good an that the course of the lactation curve is normal.

During the 2nd lactation, the CR crosses produced $3577.00 \mathrm{~kg}$ of milk, group C produced by $333.23 \mathrm{~kg}$ less and the CA crosses by $460.19 \mathrm{~kg}$ less than group CR. Tab. 4 gives the results of statistical analyses. The fat content was the highest in the $C R$ crosses, i. e. $4.23 \%$, in CA crosses and group C it was by $0.05 \%$ and $0.10 \%$ lower, respectively. The total amount of fat in $\mathrm{kg}$ was $151.16 \mathrm{~kg}$ in the CR crosses and as compared with them it was by $17.35 \mathrm{~kg}$ and $21.45 \mathrm{~kg}$ lower in group C and CA crosses, respectively. The index of persistence for the 2 nd lactation in all the breeding groups ranged between 66.95 in the CR group and 67.49 in CA, which gives evidence that the level of persistence is not very satisfactory and that the lactation curve is very steep.

During the $3 r d$ lactation, the CR crosses produced $3885.31 \mathrm{~kg}$ of milk, group C produced by $281.78 \mathrm{~kg}$ less and the CA crosses by $327.07 \mathrm{~kg}$ less than the CR crosses. Tab. 5 also gives the result of statistical analyses. The highest fat content in per cent - $4.37 \%$ - was found in the CA crosses and compared with them it was by $0.21 \%$ and $0.27 \%$ lower in the CR crosses and group C, respectively. The highest amount of fat in $\mathrm{kg}$ was produced by the CR crosses - $161.34 \mathrm{~kg}$, followed by the CA crosses and group C which produced by $5.49 \mathrm{~kg}$ and $13.39 \mathrm{~kg}$ of $\mathrm{fat}$ less than the CR crosses, respectively. The values of the index of persistence in all the breeding groups compared again gave evidence of the fact that the level of persistence was not very satisfactory and that the lactation curve was very steep.

Results of statistical analysis of an average amount of milk for the individual standardized lactations within the experimental groups are given in Tab. 6.

Within the individual breeding groups, the occurrence of abnormal lactations according to their sequence was compared, as can be seen in Tab. 7. Lactations shorter than 250 days were taken as abnormal. In group CR, the highest per cent of abnormal 
Milk yield during lst lactation (mathematical-statistical characteristics, $F$ - test and $t$ - test)

\begin{tabular}{|c|c|c|c|c|c|c|c|c|c|c|}
\hline \multirow[b]{2}{*}{ Index } & \multirow{2}{*}{ 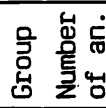 } & \multirow[b]{2}{*}{$\bar{x}$} & \multirow[b]{2}{*}{ SD } & \multirow[b]{2}{*}{ SEM } & \multirow[b]{2}{*}{$v \%$} & \multicolumn{2}{|c|}{$F$ - test } & \multirow{2}{*}{$\begin{array}{l}\text { Groups } \\
\text { compar- } \\
\text { ed }\end{array}$} & \multicolumn{2}{|c|}{$t-$ test } \\
\hline & & & & & & value & $\begin{array}{l}\text { signi- } \\
\text { ficance }\end{array}$ & & value & $\begin{array}{l}\text { Signi- } \\
\text { ficance }\end{array}$ \\
\hline $\begin{array}{l}\text { milk } \\
\text { in } \mathrm{kg}\end{array}$ & $\begin{array}{ll}\text { CR } & 62 \\
\text { C } & 48 \\
\text { CA } & 65\end{array}$ & $\begin{array}{l}3446.1 \\
2964.0 \\
3094.9\end{array}$ & $\begin{array}{l}648.0 \\
581.8 \\
624.5\end{array}$ & $\begin{array}{r}82.3 \\
83.97 \\
77.5\end{array}$ & $\begin{array}{l}18.2 \\
19.6 \\
20.2\end{array}$ & 9.025 & ++ & $\begin{array}{l}\text { CR:C } \\
\text { CR:CA } \\
C: C A\end{array}$ & $\begin{array}{l}3.989 \\
3.085 \\
1.119\end{array}$ & $\begin{array}{l}++ \\
++ \\
-\end{array}$ \\
\hline $\begin{array}{l}\text { fat } \\
\text { in } \%\end{array}$ & $\begin{array}{ll}\text { CR } & 62 \\
\text { C } & 48 \\
\text { CA } & 65\end{array}$ & $\begin{array}{l}4.06 \\
3.90 \\
4.11\end{array}$ & $\begin{array}{l}0.40 \\
0.26 \\
0.30\end{array}$ & $\begin{array}{l}0.05 \\
0.04 \\
0.04\end{array}$ & $\begin{array}{l}9.98 \\
6.65 \\
7.37\end{array}$ & 6.099 & ++ & $\begin{array}{l}\text { CR:C } \\
\text { CR:CA } \\
\text { C : :CA }\end{array}$ & $\begin{array}{l}2.441 \\
0.820 \\
3.946\end{array}$ & $\begin{array}{l}++ \\
- \\
++\end{array}$ \\
\hline $\begin{array}{l}\text { fat } \\
\text { in } \mathrm{kg}\end{array}$ & $\begin{array}{ll}\text { CR } & 62 \\
\text { C } & 48 \\
\text { CA } & 65\end{array}$ & $\begin{array}{l}139.1 \\
115.19 \\
127.06\end{array}$ & $\begin{array}{l}25.84 \\
22.47 \\
25.83\end{array}$ & $\begin{array}{l}3.28 \\
3.24 \\
3.20\end{array}$ & $\begin{array}{l}18.58 \\
19.51 \\
20.33\end{array}$ & 12.375 & ++ & $\begin{array}{l}\text { CR:C } \\
\text { CR:CA } \\
C \text { :CA }\end{array}$ & $\begin{array}{l}5.048 \\
2.607 \\
2.528\end{array}$ & $\begin{array}{l}++ \\
++ \\
++\end{array}$ \\
\hline $\begin{array}{l}\text { index } \\
\text { of per- } \\
\text { sist. }\end{array}$ & $\begin{array}{l}\text { CR } 62 \\
\text { C } 48 \\
\text { CA } 65\end{array}$ & $\begin{array}{l}73.61 \\
76.83 \\
76.94\end{array}$ & $\begin{array}{r}10.75 \\
11.58 \\
9.35\end{array}$ & $\begin{array}{l}1.37 \\
1.67 \\
1.16\end{array}$ & $\begin{array}{l}14.60 \\
15.07 \\
12.15\end{array}$ & 1.935 & - & $\begin{array}{l}\text { CR:C } \\
\text { CR:CA } \\
C \text { :CA }\end{array}$ & $\begin{array}{l}1.491 \\
1.848 \\
0.054\end{array}$ & - \\
\hline
\end{tabular}

$++P<0.01$

Table 4

Milk yield during 2 nd lactation (mathematical-statistical characteristics, F - test and $t$ - test)

\begin{tabular}{|c|c|c|c|c|c|c|c|c|c|c|}
\hline \multirow[b]{2}{*}{ Index } & \multirow{2}{*}{ 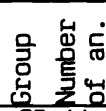 } & \multirow[b]{2}{*}{$\bar{x}$} & \multirow[b]{2}{*}{ SD } & \multirow[b]{2}{*}{ SEM } & \multirow[b]{2}{*}{$v \%$} & \multicolumn{2}{|c|}{$F$ - test } & \multirow{2}{*}{$\begin{array}{l}\text { Groups } \\
\text { compar- } \\
\text { ed }\end{array}$} & \multicolumn{2}{|c|}{$t-$ test } \\
\hline & & & & & & value & $\begin{array}{l}\text { signi- } \\
\text { ficance }\end{array}$ & & value & $\begin{array}{l}\text { signi- } \\
\text { ficance }\end{array}$ \\
\hline $\begin{array}{l}\text { milk } \\
\text { in kg }\end{array}$ & $\begin{array}{ll}\text { CR } & 44 \\
C & 31 \\
\text { CA } & 41\end{array}$ & $\begin{array}{l}3577.0 \\
3243.8 \\
3116.8\end{array}$ & $\begin{array}{l}657.95 \\
699.76 \\
628.65\end{array}$ & $\begin{array}{c}99.19 \\
125.68 \\
98.18\end{array}$ & $\begin{array}{l}18.39 \\
21.57 \\
20.17\end{array}$ & 5.351 & ++ & $\begin{array}{l}\text { CR:C } \\
\text { CR:CA } \\
C \text { :CA }\end{array}$ & $\begin{array}{l}2.075 \\
3.253 \\
0.797\end{array}$ & $\begin{array}{ll}5 & + \\
3 & ++ \\
7 & -\end{array}$ \\
\hline $\begin{array}{l}\text { fat } \\
\text { in } \%\end{array}$ & $\begin{array}{ll}\text { CR } & 44 \\
\text { C } & 31 \\
\text { CA } & 41\end{array}$ & $\begin{array}{l}4.23 \\
4.13 \\
4.18\end{array}$ & $\begin{array}{l}0.37 \\
0.26 \\
0.26\end{array}$ & $\begin{array}{l}0.06 \\
0.04 \\
0.04\end{array}$ & $\begin{array}{l}8.66 \\
6.40 \\
6.12\end{array}$ & 1.036 & - & $\begin{array}{l}\text { CR:C } \\
\text { CR:CA } \\
\text { C :CA }\end{array}$ & $\begin{array}{l}1.320 \\
0.802 \\
0.752\end{array}$ & $\begin{array}{l}- \\
-\end{array}$ \\
\hline $\begin{array}{l}\text { fat } \\
\text { in } \mathrm{kg}\end{array}$ & $\begin{array}{ll}\text { CR } & 44 \\
\text { C } & 31 \\
\text { CA } & 41\end{array}$ & $\begin{array}{l}151.16 \\
133.81 \\
129.71\end{array}$ & $\begin{array}{l}28.97 \\
31.07 \\
24.31\end{array}$ & $\begin{array}{l}4.37 \\
5.58 \\
3.80\end{array}$ & $\begin{array}{l}19.17 \\
23.22 \\
18.74\end{array}$ & 6.749 & ++ & $\begin{array}{l}\text { CR:C } \\
\text { CR:CA } \\
C \text { :CA }\end{array}$ & $\begin{array}{l}2.445 \\
3.640 \\
0.619\end{array}$ & $\begin{array}{l}++ \\
++ \\
-\end{array}$ \\
\hline $\begin{array}{l}\text { index } \\
\text { of per- } \\
\text { sist. }\end{array}$ & $\begin{array}{ll}\text { CR } & 44 \\
C & 31 \\
\text { CA } & 41 \\
\end{array}$ & $\begin{array}{l}66.95 \\
67.23 \\
67.49 \\
\end{array}$ & $\begin{array}{r}11.08 \\
8.47 \\
9.48 \\
\end{array}$ & $\begin{array}{l}1.67 \\
1.52 \\
1.48 \\
\end{array}$ & $\begin{array}{l}16.55 \\
12.59 \\
14.05 \\
\end{array}$ & 0.030 & - & $\begin{array}{l}\text { CR:C } \\
\text { CR:CA } \\
C \text { :CA }\end{array}$ & $\begin{array}{l}0.115 \\
0.237 \\
0.120 \\
\end{array}$ & - \\
\hline
\end{tabular}

Table 5

Milk yield during $3 r d$ lactation (mathematical-statistical characteristics, $F$ - test and $t$ - test)

\begin{tabular}{|c|c|c|c|c|c|c|c|c|c|c|}
\hline \multirow[b]{2}{*}{ Index } & \multirow{2}{*}{ 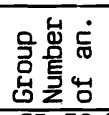 } & \multirow[b]{2}{*}{$\bar{x}$} & \multirow[b]{2}{*}{ SD } & \multirow[b]{2}{*}{ SEM } & \multirow[b]{2}{*}{$v \%$} & \multicolumn{2}{|c|}{$F$ - test } & \multirow{2}{*}{$\begin{array}{l}\text { Groups } \\
\text { compar- } \\
\text { ed }\end{array}$} & \multicolumn{2}{|c|}{$t-$ test } \\
\hline & & & & & & value & $\begin{array}{l}\text { signi- } \\
\text { ficance }\end{array}$ & & value & $\begin{array}{l}\text { signi- } \\
\text { ficance }\end{array}$ \\
\hline $\begin{array}{l}\text { milk } \\
\text { in kg }\end{array}$ & $\begin{array}{ll}\text { CR } & 32 \\
\text { C } & 19 \\
\text { CA } & 34\end{array}$ & $\begin{array}{l}3885.31 \\
3603.53 \\
3558.24\end{array}$ & $\begin{array}{l}754.921 \\
640.021 \\
542.22\end{array}$ & $\begin{array}{r}133.45 \\
146.83 \\
92.98\end{array}$ & $\begin{array}{l}19.43 \\
17.76 \\
15.24\end{array}$ & 2.223 & - & $\begin{array}{l}\text { CR:C } \\
\text { CR:CA } \\
C: C A\end{array}$ & $\begin{array}{l}1.335 \\
1.999 \\
0.286\end{array}$ & $\begin{array}{l}- \\
-\end{array}$ \\
\hline $\begin{array}{l}\text { fat } \\
\text { in } \%\end{array}$ & $\begin{array}{ll}\text { CR } & 32 \\
\text { C } & 19 \\
\text { CA } & 34\end{array}$ & $\begin{array}{l}4.16 \\
4.10 \\
4.37\end{array}$ & $\begin{array}{l}0.46 \\
0.26 \\
0.28\end{array}$ & $\begin{array}{l}0.08 \\
0.06 \\
0.05\end{array}$ & $\begin{array}{r}11.15 \\
6.28 \\
3.41\end{array}$ & 4.220 & + & $\begin{array}{l}\text { CR:C } \\
\text { CR:CA } \\
C: C A\end{array}$ & $\begin{array}{l}0.553 \\
2.179 \\
3.412\end{array}$ & $\begin{array}{l}- \\
+ \\
++\end{array}$ \\
\hline $\begin{array}{l}\text { fat } \\
\text { in } \mathrm{kg}\end{array}$ & $\begin{array}{ll}\text { CR } & 32 \\
\text { C } & 19 \\
\text { CA } & 34\end{array}$ & $\begin{array}{l}161.34 \\
147.95 \\
155.85\end{array}$ & $\begin{array}{l}30.05 \\
30.55 \\
27.36\end{array}$ & $\begin{array}{l}5.31 \\
7.00 \\
4.89\end{array}$ & $\begin{array}{l}18.63 \\
20.65 \\
17.55\end{array}$ & 1.219 & - & $\begin{array}{l}\text { CR:C } \\
\text { CR:CA } \\
C \text { :CA }\end{array}$ & $\begin{array}{l}1.500 \\
0.765 \\
0.947\end{array}$ & - \\
\hline $\begin{array}{l}\text { index } \\
\text { of per- } \\
\text { sist. }\end{array}$ & $\begin{array}{r}\text { CR. } 32 \\
- \text { C } 19 \\
\text { CA } 34 \\
\end{array}$ & $\begin{array}{l}65.25 \\
68.00 \\
67.15 \\
\end{array}$ & $\begin{array}{r}6.28 \\
8.28 \\
10.24 \\
\end{array}$ & $\begin{array}{l}1.46 \\
1.90 \\
1.76\end{array}$ & $\begin{array}{l}12.68 \\
12.18 \\
15.25 \\
\end{array}$ & 0.621 & - & $\begin{array}{l}\text { CR:C } \\
\text { CR:CA } \\
C \text { :CA }\end{array}$ & $\begin{array}{l}1.124 \\
0.813 \\
0.303 \\
\end{array}$ & $\begin{array}{l}- \\
-\end{array}$ \\
\hline
\end{tabular}


Table 6

Comparison of milk yield according to sequence of lactations in the individual breeding groups

\begin{tabular}{|c|c|c|c|c|c|c|c|}
\hline \multirow{2}{*}{ Index } & \multirow{2}{*}{ Group } & \multirow{2}{*}{\multicolumn{2}{|c|}{$\begin{array}{l}\text { sequence } n \\
\text { of lacta- } \\
\text { tions }\end{array}$}} & \multirow{2}{*}{$\bar{x}$} & \multirow{2}{*}{$\begin{array}{l}\text { Lactations } \\
\text { compared }\end{array}$} & \multicolumn{2}{|c|}{$t$ - test } \\
\hline & & & & & & value & $\begin{array}{l}\text { signi- } \\
\text { ficance }\end{array}$ \\
\hline \multirow[b]{2}{*}{$\stackrel{\square}{x}$} & CR & $\begin{array}{l}\text { I } \\
\text { II } \\
\text { III }\end{array}$ & $\begin{array}{l}62 \\
44 \\
32\end{array}$ & $\begin{array}{l}3446.05 \\
3577.00 \\
3885.31\end{array}$ & $\begin{array}{l}\text { I : II } \\
\text { I }: \text { III } \\
\text { II }: \text { III }\end{array}$ & $\begin{array}{l}1.009 \\
2.909 \\
1.869\end{array}$ & $\begin{array}{l}- \\
++ \\
-\end{array}$ \\
\hline & & $\mathrm{I}=$ & $-\frac{2}{48}$ & -2963.96 & $\mathrm{I}-\overline{I I}$ & 1.901 & $=-$ \\
\hline .5 & $C$ & II & $\begin{array}{l}31 \\
19\end{array}$ & $\begin{array}{l}3243.77 \\
3603.53\end{array}$ & I : III & $\begin{array}{l}3.881 \\
1.785\end{array}$ & + \\
\hline \multirow[t]{4}{*}{$\underset{\stackrel{\sim}{\mathscr{V}}}{\stackrel{\sim}{E}}$} & $C A$ & II & $\begin{array}{l}65 \\
41 \\
34\end{array}$ & $\begin{array}{l}3094.92 \\
3116.81 \\
3558.24\end{array}$ & $\begin{array}{l:l}I & \text { II } \\
\text { I } & : \text { III } \\
\text { II } & : \text { III }\end{array}$ & $\begin{array}{l}0.174 \\
3.626 \\
3.177\end{array}$ & $\begin{array}{l}2 \\
++ \\
++\end{array}$ \\
\hline & \multirow{3}{*}{ CR } & I & 62 & 4.06 & I : II & 2.220 & + \\
\hline & & II & 44 & 4.23 & $\bar{I}:$ III & 1.105 & - \\
\hline & & III & 32 & 4.16 & II_:III & 0.693 & $=-$ \\
\hline$x$ & & $I$ & $4 \overline{8}$ & 3.89 & $I: I I$ & $3 . \overline{8} \overline{2} \overline{6}$ & ++ \\
\hline \multirow{2}{*}{$\stackrel{5}{\cdot-1}$} & C & II & 31 & 4.13 & I : III & 2.866 & ++ \\
\hline & & III & $-\frac{19}{65}$ & $-\frac{4}{4} \cdot 10$ & II : III & 0.373 & $=-$ \\
\hline \multirow{2}{*}{$\underset{\pi}{\infty}$} & CA & II & 41 & 4.18 & : III & 4.095 & ++ \\
\hline & & III & 34 & 4.37 & II : III & 3.106 & ++ \\
\hline \multirow{4}{*}{$\underline{\not}$} & \multirow[b]{2}{*}{ CR } & I & 62 & 139.11 & I : II & 2.215 & + \\
\hline & & II & 44 & 151.16 & $I:$ III & 3.694 & ++ \\
\hline & & III & $-\frac{32}{48}$ & 161.34 & II & $\begin{array}{r}1.469 \\
-3.0747\end{array}$ & $\overline{++}$ \\
\hline & C & II & 31 & 133.81 & $\bar{I}:$ III & 4.757 & ++ \\
\hline .5 & & III & 19 & 147.95 & II : III & 1.540 & $=$ \\
\hline \multirow{3}{*}{$\underset{4}{+\infty}$} & & I & & & $I: I I$ & 0.521 & - \\
\hline & CA & II & 41. & 129.71 & $I: I I I$ & 5.100 & ++ \\
\hline & & III & 34 & 155.85 & II : III & 4.320 & ++ \\
\hline \multirow{8}{*}{ 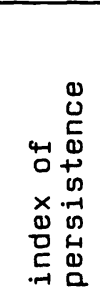 } & & $\mathrm{I}$ & 62 & 73.61 & I : II & 3.075 & ++ \\
\hline & CR & II & 44 & 66.95 & $I: I I I$ & 3.610 & ++ \\
\hline & & III & 32 & & II : III & 0.722 & $\therefore=$ \\
\hline & & & & & $I: I I$ & & \\
\hline & C & II & 31 & 67.23 & I : III & 2.986 & ++ \\
\hline & & $I=$ & 65 & 76.94 & $\mathrm{I}-\div$ & 4.993 & $\mp+$ \\
\hline & CA & II & 41 & 67.49 & I : III & 4.736 & t+ \\
\hline & & III & 34 & 67.15 & II : III & 0.146 & - \\
\hline
\end{tabular}

$+P<0.05$

$++P<0.01$ 
Table 7

Percentage of abnormal lactations in the experimental groups

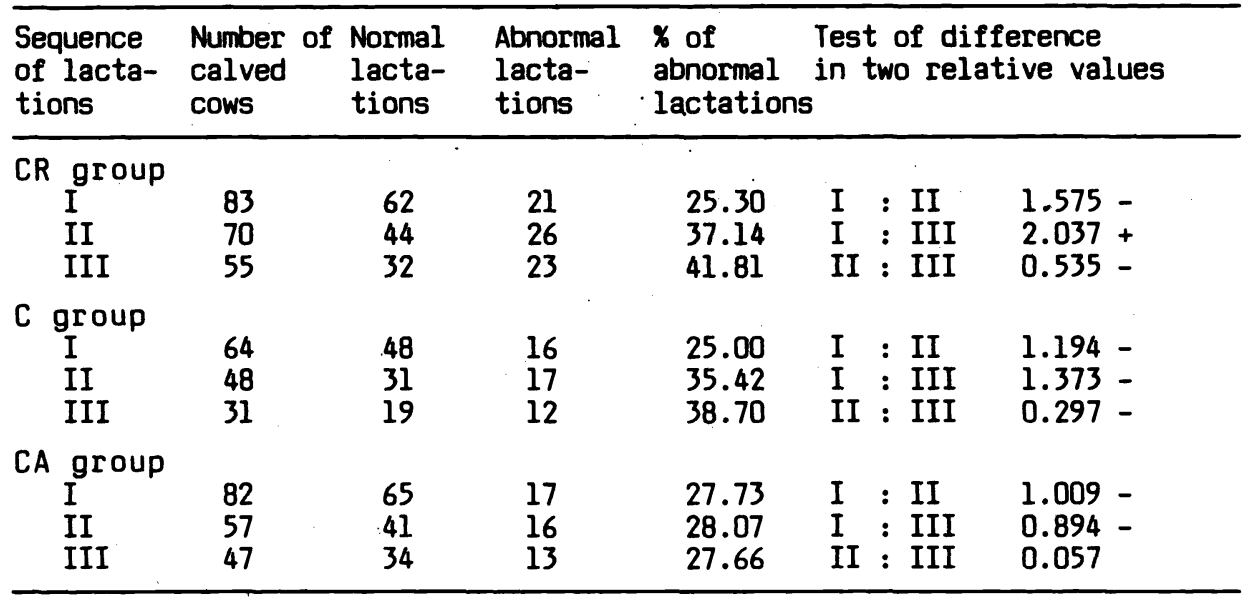

$+P<0.05$

Test of difference in two relative values among groups

lst lactation

CR : C 0.042 -

$C R$ : CA 0.702

$C$ : CA 0.616 -

\section{2nd lactation}

CR : C 0.222 -

CR : CA 1.073 -

C : CA 0.771 - 3rd lactation

CR : C 0.281 -

$C R: C A \quad 1.497-$

C : CA 1.028 -

Table 8

Comparison of the investigated groups with CR crosses raised at the Bartosovice farm

\begin{tabular}{|c|c|c|c|c|c|c|c|c|c|c|c|}
\hline \multirow{2}{*}{ Index } & \multirow[b]{2}{*}{$n$} & CR & \multicolumn{2}{|r|}{ C } & \multicolumn{2}{|c|}{ CA } & \multicolumn{2}{|c|}{ CR(B) } & \multirow{2}{*}{$\begin{array}{l}\text { Groups } \\
\text { compared }\end{array}$} & \multicolumn{2}{|c|}{ t-test } \\
\hline & & $\bar{x}$ & $n$ & $\bar{x}$ & $n$ & $\bar{x}$ & $n$ & $\bar{x}$ & & value & $\begin{array}{l}\text { signi- } \\
\text { fic. }\end{array}$ \\
\hline milk in $\mathrm{kg}$ & 62 & 3446.05 & 482 & 2963.96 & 65 & 3094.92 & 36 & 3291.72 & $\begin{array}{l}2 \text { CR:CR(B) } \\
C \text { :CR(B) } \\
C A: C R(B)\end{array}$ & $\begin{array}{l}0.64 \\
2.57 \\
1.57\end{array}$ & $\begin{array}{l}- \\
++ \\
-\end{array}$ \\
\hline fat in $\%$ & 62 & 4.06 & 48 & 3.90 & 65 & 4.11 & 36 & 3.94 & $\begin{array}{l}C R: C R(B) \\
C: C R(B) \\
C A: C R(B)\end{array}$ & $\begin{array}{l}1.55 \\
0.61 \\
2.66\end{array}$ & $\begin{array}{l}- \\
- \\
++\end{array}$ \\
\hline fat in $\mathrm{kg}$ & 62 & 139.11 & 48 & 115.19 & 65 & 127.06 & 36 & 128.81 & $\begin{array}{l}C R: C R(B) \\
C: C R(B) \\
C A: C R(B)\end{array}$ & $\begin{array}{l}2.02 \\
2.80 \\
0.35\end{array}$ & $\begin{array}{l}+ \\
++ \\
-\end{array}$ \\
\hline $\begin{array}{l}\text { index } \\
\text { of per- } \\
\text { sistence. }\end{array}$ & 62 & 73.61 & $48^{\circ}$ & 76.83 & 65 & 76.94 & 36 & 77.03 & $\begin{array}{l}\text { CR:CR(B) } \\
C \text { :CR(B) } \\
C A: C R(B)\end{array}$ & $\begin{array}{l}1.63 \\
0.09 \\
0.05\end{array}$ & $\begin{array}{l}- \\
-\end{array}$ \\
\hline $\begin{array}{l}\% \text { of abnor- } \\
\text { mal lacta- } \\
\text { tions }\end{array}$ & & 25.30 & & 25.00 & & 20.73 & & 25.00 & $\begin{array}{l}C R: C R(B) \\
C: C R(B) \\
C A: C R(B)\end{array}$ & $\begin{array}{l}0.04 \\
0 \\
0.52\end{array}$ & - \\
\hline
\end{tabular}


lactations was $41.81 \%$ in the $3 r d$ lactation, and the lowest in the lst lactation - $25.30 \%$. In group $C$, the highest per cent of abnormal lactations was $38.70 \%$ in the $3 r d$ lactation and the lowest in the lst lactation - $25.00 \%$. In group CA, the highest per cent of abnormal lactations was $28.07 \%$ in the 2 nd lactation and the lowest in the 3rd lactation - $27.66 \%$.

The experimental groups CR, $C$ and CA were compared with the control group of contemporaries, CR crosses (B) raised in a different environment on their lst lactation. Tab. 8 gives the results of this comparison. Milk yield was the highest in the experimental group $C R$ and averaged $3446.05 \mathrm{~kg}$ of $\mathrm{milk}$, the CR (B) group produced by $154.33 \mathrm{~kg}$ of milk less. The fat percentage was the highest in CA crosses $(4.11 \%$ ), in the CR group (B) it was by $0.17 \%$ lower. The total amount of $\mathrm{fat}$ in $\mathrm{kg}$ was the highest in the CR crosses - $139.11 \mathrm{~kg}$, in the CR group (B) it was by $10.30 \mathrm{~kg}$ lower. The index of persistence of the three breeding groups investigated did not considerably differ from the index of persistence of the CR crosses (B) where the value was $77.03 \%$, showing a good level of persistence and a normal course of the lactation curve. As concerns the occurrence of abnormal lactations, no differences were found between the experimental. groups and group CR (B).

Fig. l compares the milk yield of the three breeding groups investigated with that of their mothers. Comparisons of the group of CR crosses with their mothers in the

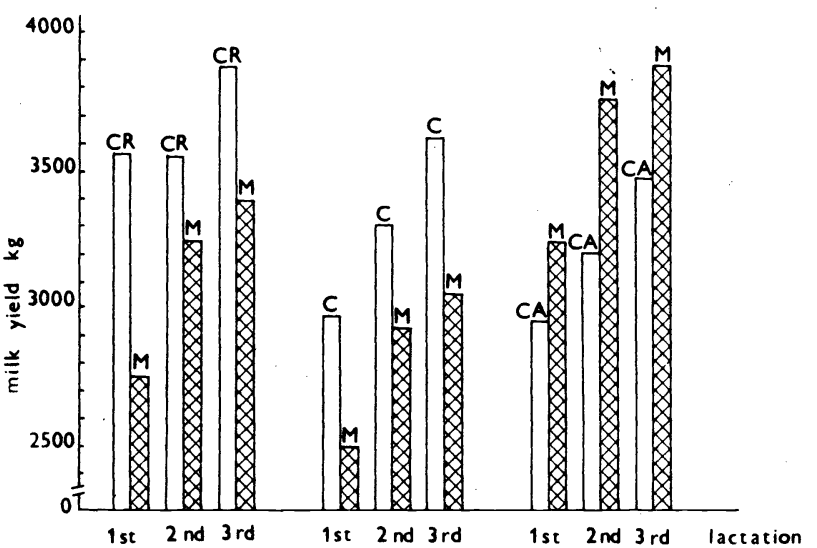

Fig. 1. Comparison of the milk yield of breeding groups investigated with that of their mothers. average milk yield of the individual lactations were all in favour of the experimental group of $C R$ crosses. A highly significant difference between the experimental group CR and their mothers was observed only in the lst lactation. In group $C$, the average milk yield was again higher than in their mothers. There is a highly significant difference also in the lst lactation. In CA crosses, the average amount of milk in $\mathrm{kg}$ in all lactations is lower than in their mothers: There is a significant difference in the lst and 3 rd lactation and a highly significant difference in the 2nd lactation in favour of the mothers. The mothers of the CA crosses were dairy cows whose milk yield was above the average of the herd. They were stanchion housed on litter under optimal conditions of nutrition. In the comparative experiment, their CA daughters were stanchion housed 
together with other groups of $C$ and $C R$ with a dung grid and under different nutrition. In such changed conditions their is a relative decrease in the performance of CA daughters as compared with their mothers.

\section{Discus s i o n}

The crossing of the Bohemian Pied breed with dairy breeds was to accelerate the improvement process in order to increase milk production and also to improve the morphological and physiological properties of the milk gland. The aim of this improvement process was to form a combined performance type with a predominating milk yield.

According to $S$ uchánek et al. (1982), milk production of the CA crosses in the lst lactation was higher in 1970 by $384 \mathrm{~kg}$ and by $241 \mathrm{~kg}$ of $\mathrm{milk}$ in 1980 as compared with the Czech Red Pied breed. The authors explains that this decrease in the difference of the yield is due to the fluctuating proportion of CA crosses and quicker increase of yield in cows of the Czech Red Pied breed in the course of the experimental years.

Many authors dealt with the evaluation of milk yield of the CA crosses as compared with contemporaries of the Bohemian Pied breed. Suchánek et al. (1972), S uchánek (1973, 1978, $1980,1982), \mathrm{U} \mathrm{l} \mathrm{r} \mathrm{y} \mathrm{ch} \mathrm{and} \mathrm{Such}$ ánek (1981) stated that milk yield in the CA crosses was higher by $220-993 \mathrm{~kg}$ of milk and fat content was higher by $0.01-0.06 \%$ of fat as compared with dairy cows of group $C$.

In the group of CA crosses investigated in the present study, milk production was found to increase with further lactations as well as the fat percentage. When comparing milk production of the CA crosses with dairy cows of group $C$, the difference in milk production for the lst lactation was $130.96 \mathrm{~kg}$ in favour of the CA crosses, in the 2 nd and 3 rd lactations in favour of group $C$. Fat percentage in the lst lactation was by $0.21 \%$ higher in the CA crosses, in the 2nd lactation by $0.05 \%$ and in the $3 \mathrm{rd}$ lactation by $0.27 \%$. The total amount of fat given in $\mathrm{kg}$ was by $11.87 \mathrm{~kg}$ higher in the CA crosses in the lst lactation, in the 2nd lactation by $4.10 \mathrm{~kg}$ higher in group $C$ and in the $3 \mathrm{rd}$ lactation by $7.90 \mathrm{~kg}$ higher in the Ca crosses. The results obtained in the dairy cows investigated showed that milk yield in the lst lacta$t i o n$ was in favour of the CA crosses, however, in the 2 nd and 3rd lactations in favour of group $C$, through it is true that this was statistically insignificant.

If the differences given in the present paper in some of the indices of performance are not quite identical with data of other authors, they can be due to the differences in the breeding groups compared, number of animals, different genetic pool and to many external and internal factors under which were these comparison performed. The relatively favourable results obtained in group $C$ are also the result of selection of cows and the use of improvement bulls.

Suchánek et al. (1975), in his evaluations of the performance indices of the CR crosses, reported that the average amount 
of milk produced in the lst lactation was $4775 \mathrm{~kg}$ and the fat percentage $3.60 \%$; when evaluated using the CC-test it was by $1903 \mathrm{~kg}$ of milk less and by 0.49 \% lower fat percentage than in their contemporaries of group C. L i z a l (1979) evaluated the CR 25 crosses which produced $1292 \mathrm{~kg}$ of milk with $3.91 \%$ of fat in 100 lactation days, what is by $159 \mathrm{~kg}$ of milk and $5.8 \mathrm{~kg}$ of fat more than contemporaries of group C. S u chá nek (1980, $1981,1982,1983$ ), S u chá nek and Golda (1983), Vách a l (1983) evaluated milk yield in CR crosses and found that milk production increased by $298-625 \mathrm{~kg}$ and fat percentage decreased by $0-0.10 \%$ as compared with contemporaries of group $C$. The differences in milk yield did not change considerably with the sequence of lactations.

In the breeding groups of CR crosses investigated in the present study, the fat percentage was higher as compared with group $C$; so, in accord with the data of $V$ ách a l (1983), the fat content of milk did not decrease with the sequence of lactations. The results of milk yield correspond, in essence, with results of other authors and the majority of indices investigated are in favour of the $C R$ crosses. Mutual comparisons of all three breeding groups showed that the CR crosses had the highest milk $y$ ield and total amount of $\mathrm{fat}$ in $\mathrm{kg}$ in all the three lactations. In the 2 nd and 3 rd lactations, the breeding cows of group $C$ had somewhat higher, if insignificant, performance parametres and thus came close to both of the groups of crosses CR and CA compared. This finding can be explained, on the one hand, by the level of nutrition which was apparently not sufficient for a better manifestation of the genotype in the CR and CA crosses. Within the three groups investigated, the sensitivity and response to the given conditions was the highest because it was mainly in dairy cows with a milk production higher than the average of the group that the condition became worse during maximum lactation.

Similar to Suchánek et al. (1984), none of the groups of $C R$ and $C A$ crosses compared in the present study showed a significant difference in the persistence of the lactation curve $P_{2: 1}$ in relation to breeding cows of group $C$.

Genetický přinos mléčné užitkovosti křiženek českého strakatého plemene s červeným holštýnským a ayrshirským

Křiženky CR dosáhly nejvyšsí mléčné užitkovosti ve srovnání s křiženkami CA a plemenicemi $C$ na všech třech laktacích. Rovněž pŕiznivé hodnoty se projevily u křženek CR $v$ procentuálním obsahu tuku i v celkovém množství tuku. Větši citlivost a reaktivnost na dané podminky chovu se projevila u kł̌iženek CR zhoršením jejich kondice $v$ době maximální laktace. V indexu persistence $\mathrm{P}_{2}$ nebylo mezi srovnávanými skupinami zjištěno podstatných różłlú. Na I. laktaci byl stupeñ persistence u všech trí plemenných skupin dobrý s normálním prüběhem laktační kîivky, zatímco na II. a III. laktaci byla persistence méně uspokojivá se sklonem $k$ pŕfkrému prúběhu laktačni křivky. Procento nenormálnich laktaci činilo kolem $25 \%$ na I. laktaci u vsech tí plemenných skupin. S postupujicími laktacemi došlo k větsímu výskytu 
nenormálních laktaci u kírženek CR a plemenic skupiny C, zatímco kł́iženky CA měly procento nenormálnich laktací nejmenší. Płi srovnáni výše mléčné užitkovosti sledovaných plemenných skupin dojnic s užitkovostí matek vykázaly kíiženky CR na všech laktacích vyšsi mléčnou produkci, přičemž na I. laktaci byl tento rozdíl vysoce prưkazný. Obdobný výsledek byl zjištěn u plemenic $C$, zatímco křiženky CA nedosáhly na všech třech laktacích užitkovosti svých matek.

Генетический вхлад в молочную продухтивность помесей
четского пятнистого с храсным гольштейнским и
айтирским племенами

Помеси CR достигли махсимальной молочной продуктивности по сравнению С помесями СА и племенными матками С во всех трех лактациях. Благоприятные величины были также установлены у помесей $C R$ в процентном содержании и общем количестве жира. Большая чувствительность и реакционная способность в данных условиях животноводства проявились у помесей CR в ухудшении их кондиции в период махсимальной лахтации. В индексе персистенции $\mathrm{P}_{2: 1}$ между сопоставляемыми группами не было установлено существенной разницы. В 1 лактации степень персистенции всех трех племенных групп была хорошая с нормальным протеканием кривой лактации, между тем как во II и III лактации персистенция была менее удовлетворительной с тенденцией $\mathbf{x}$ крутому протеканию кривой лактации. Процент ненормальных лактаций достигал около 258 в 1 лактации всех трех племенных групп. В последующих лактациях наблюдается большее количество ненормальных лахтаций у помесей CR и племенных матох группы C, между тем как процент ненормальных лактаций у помесей СА был наименьший. Сравнивая уровень молочной продуктивности исследуемых племенных групп дойных коров C производительностью маток, помеси CR отличались в период всех лактаций большей молочной продуктивностью, при этом упомянутая разница в 1 лактации весьма значчимой. Аналогичные результаты были установлены у племенных маток C, между тем как помеси CA во всех трех лактациях не достигли продуктивности своих маTOX.

BAUMGARTNER, H. - HUTZLI, H.: Kreutzung der roten Holsteinrasse mit Simmentaler Fleckvieh. Mitt. Bull., 2, 1976: $30-37$.

BRAUNER, J. - SUCHÁNEK, B.: Složeni a vlasṫnosti mléka u krav v I. laktaci ve vztahu k některým činitelům. Živoč. Výr., 27, 1982: 99 - 108 .

JONGELING, C.: Umfang und Möglichkeiten des Einsatzes von Fremdgenen in der deutschen Rotbuntzucht. Tierzüchter, 33, 1981: $322-325$.

KOUBIK, M.: Dva nové šlechtitelské chovy. Zeměd. Nov., Zemědělec, 11.11 .1981 .

LIZAL, F.: Nové poznatky výzkumu především na úseku prủmyslového odchovu jalovic. Výzk. Chovu Skotu, 21, 1979: $12-16$.

OPfCHAL, Z.: Vývoj zušlechtovacího a užitkového kŕížení skotu $\checkmark$ severomoravském kraji. Výzk. Chovu Skotu, 21, 1979: 31 - 35. 
RUEGSEGGER, A.: Les résultats les plus importants des performances laitières des produits croisés Simmental x Red Holstein de l annés de contrôle 1976/77. Mitt. Bull., 2, Fédération suisse d’élavage de la race tachetée rouge, 1978: $17-28$.

SCHMIDLIN, J.: Milchleistung und Fruchtbarkeit von simmentalern und Kreutzungen mit Red Holstein. KB Mitt. Schweiz. Verb. f. künstl. Besam. u. Arb. - Gemeinsch. f. künstl. Besam., 18, 1980: 106 - 110 .

SOKOLOVA, A.: Ispolzovanije golštino-frizov v promyšlennom skroščivanii. Moloč. mjas. Skotov., Moskva, 1979: 31 - 33.

SUCHÁNEK, B.: Zhodnocení zušlechtovacího křižení českého strakatého skotu s ayrshirským plemenem ve vybraných chovech. Project report, Rapotín, VÚCHS, 1970: 70.

SUCHANEK, B. - ULRYCH, A. - PILAT, Z.: Mléčná užitkovost kǐíženek českého strakatého plemene s ayrshirským. Živoč. Výr., 17, 1972: $147-156$.

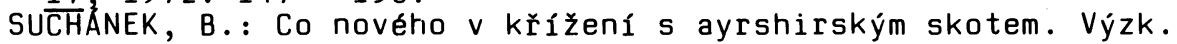
Chovu Skotu, 15, 1973: 46 - 49 .

SUCHÁNEK, B. - GOLDA, J. - PTÁČEK, J.: Zušlechtovací křížení českého strakatého plemene s červenostrakatým nížinným. Project report, Rapotín, VúCHS, 1975: 41.

SUCHÁNEK, B.: Mléčná užitkovost křiženek plemene českého strakatého a ayrshirského z hlediska dlouhověkosti. Výzk. Chovu Skotu 20, 1978: $22-24$.

SUCHÂNEK, B. - GOLDA, J.: Předběžné výsledky křižení českého strakatého plemene s červeným holštýnským skotem. Náš Chov, 39, 1979: 110 - 114 .

SU $\overline{C H A ̊ N E K, ~ B . ~-~ P O L E S, ~ V . ~-~ U L R Y C H, ~ A .: ~ M l e ́ c ̌ n a ́ ~ u z ̌ i t k o v o s t ~ k r ̌ i ́ z ̌ e-~}$ nek $V$ I. laktaci při zušlechtovacím křižení českého strakatého skotu s dojnými plemeny. Výzk. Chovu Skotu, 22, 1980: 5 - 13 .

SUCHÁNEK, B.: Výsledky kontroly užitkovosti za rok 1979 se zřetelem na užitkové typy skotu. Výzk. Chovu Skotu, 22, 1980: $14-16$.

SUCHÁNEK, B.: Zásady pro připařování v chovech začleněných do zušlecht̆ovacího křížní plemene českého strakatého s červeným holštýnským pro období 1981-1983. Výzk. Chovu Skotu, 23, 1981 : $22-24$.

SUCHÁNEK, B.: Sest vynikajících býků - kříženců ( $v$ JZD Fryšák 1980-81). Zeměd. Nov., Zemědělec. 5.1.1982: 3.

SUCHÁNEK, B. - CIBULA, M. - FASKKO, J. - CHRENEK, J. - PÁLENIK, S. - PLESNIK, J. - URBAN, F.: Užitkové typy skotu vं Československu. SZN, Praha, 1982: 295.

SUCHÁNEK, B.: Vytváření typú skotu ve velkokapacitních kravínech. Výzk. Chovu Skotu, 24, 1982: 18-24.

SUCHÁNEK, B.: Vliv individuality býkủ na výsledky křižení s červeným holštýnským skotem. Živoč. Výr., 28, 1983: 883 - 890.

SUCHÁNEK, B. - GOLDA, J.: Užitkovost kříženek českého strakatého skotu s červeným holštýnským skotem. Živoč. Výr., 28, 1983: $161-167$.

SUCHÁNEK, B. - GOLDA, J. - ULRYCH, A. - STRNADEL, Z . : Výsledky zušlechtovacího kř́žení českého strakatého plemene s ayrshirským a červeným holštýnským. Project report, Rapotín, VúcHS, $1984: 52$.

ULRYCH, A. - SUCHÁNEK, B.: Užitkovost křiženek ve velkokapacitních kravínech. Výzk. Chovu Skotu, 23, 1981: 5-14.

VACHAL, J.: Realizace komplexního programu šlechtění českého strakatého skotu. Project report, Uhříněves, VúžV, 1983: 75. 